\title{
Construction Digital Library towards Resources Sharing in the ASEAN Countries
}

\author{
Do Thi Thanh Thuy
}

\begin{abstract}
In modem society, information resources have become important strategic resources for our survival and development. Sharing information resources is a common aspiration. Document resources sharing is the basis of modem document services, and also the working target of the document workers and the key point is the development of digital resources. The purpose of digital resources development is to use and share library information resources effectively, and ultimately fulfill the Southeast Asia and global sharing. It is impossible for any single library, region or country to achieve the digital resources development alone, but to make libraries in various trades and industries and of the whole world play their roles to carry out the development and sharing. This paper discusses the necessity, feasibility and benefits, of developing and sharing Asian library digital document resources, analyses the significance of library digital document resources development and sharing, puts forward some suggestions on ways of Asian library digital document resources sharing in the network environment. This paper focuses on the necessity, feasibility and benefits, of developing and sharing Asian library digital document resources, analyses the significance of library digital document resources development and sharing, puts forward some suggestions on ways of Southeast Asia library digital document resources sharing.
\end{abstract}

Index Terms-Digital library, library cooperation, resources sharing, southeast asia, ASEAN.

\section{INTRODUCTION}

Most libraries in today's world are hybrid libraries, a mix of traditional and digital library. With time, however, digital library has greater role and function for the fact that having more information and knowledge gives competitive edge not only to individuals but the nation as well. This explains why countries around the world are putting efforts to build the digital libraries for users to have easy access to information they need. However, it is almost impossible for a single library to collect and provide overflowing knowledge and information to users so domestic and overseas libraries should cooperate together. Each library provides different leves of services, on top of the gaps between nations. The challenge therefore, facing libraries around the world is to find a cooperative measure to provide information so that users use it freely and equally. Libraries in ASEAN 10 countries are no exception in such challenge.

\section{REVIEW OF LITERATURE}

Resource sharing programs help libraries remedy their

Manuscript received October 9, 2013; revised December 9, 2013.

Do Thi Thanh Thuy is with the School of Information Management, wuhan university, China (e-mail: thuytvbg@gmail.com). collection insufficiencies and broaden the scope of resources that users can access. Kent (1978) [1] stated that when it comes to cost, libraries have the capability to use their money much more effectively and provide better services. Via interlibrary loan or document delivery arrangements, users can borrow from (or access materials at) other libraries when the needed materials are not available at the local library. Chrzastowski and Anthes (1995) [2] indicated that document delivery services could bridge the gaps caused by print journal cancelation. They reported that patrons agree that libraries may cancel low-use or cost-ineffective journals as long as articles could be provided from other sources. Facing the challenge of increasing cost for electronic resources, Lee (2000) [3] mentioned that the standard response from academic libraries was to borrow instead of purchase. But, Zopfi-Jordan (2008) [4] reported that for some inexpensive items, it is cheaper to purchase rather than borrow. Regardless of whether the library's decision is purchasing or borrowing, resource sharing among libraries is still necessary and important. Street (2003) [5] indicated that the most important goals of resource sharing are finding the location of material and getting the material. Library users expect to obtain material quickly but are not concerned about the original library location of the material. Knowing the location of material and being able to get the material for users are the responsibilities of the librarian. Perrault (1994) [6] indicated that "library resource sharing would not work if no library owns the materials sought" (pp. 16). Therefore, the libraries which own the needed materials should provide an unbiased and efficient lending mechanism.

Resource sharing has been the goal of libraries for many centuries. There is no one library that can afford to build a collection that is sufficiently comprehensive to satisfy all of its users' requests. By joining cooperative acquisition or collection development programs, libraries provide their users greater range of library materials or better depth of subject coverage (Evans \& Saponaro, 2005) [7].

Interlibrary loan (ILL) services facilitate the sharing of resources among libraries. As stated in ALA Interlibrary Loan code for the United States, "the purpose of interlibrary loan is to obtain, upon request of a library user, material not available in the user's local library" (American Library Association, 2008) [8]. The increasing amount of electronic resources in libraries may have affected the use of ILL services. A study conducted by Egan (Egan, 2005) [9] indicated that the requests for nonreturnable, photocopied materials decreased because there are more full-text e-journals available online now. Wiley and Chrzastowski (2005) [10] found that the requests for periodical articles fell $26 \%$ between 1990 and 2003 because libraries started subscribing to more packaged periodical databases. An investigation conducted by Beaubien (2007) [11] found that 
requests for nonreturnable materials decreased $4 \%$ while the requests for returnable materials (books, audio-visual materials, microfiches, etc.) increased $26 \%$ from 1998 to 2004. Walton (2008) [12] explained that the convenience of electronic resources did change the users' information behavior and that they prefer accessibility over resource quality. Meanwhile, the growth of open access resources also reduces the number of requests for ILL. Jackson (2000) [13] pointed out that users will not request in-print materials or common books owned by other libraries; rather, they would request old or special materials. Porat and Fine (2009) [14] reported on a study conducted in Israeli institutions, which found that book borrowing continues in the field of humanities, especially for esoteric and non-English books.

There is no library that can completely satisfy their users' needs, especially in the case of university libraries. The idea of "a single research resource" was raised which views the libraries in a nation as a whole (Fletcher, 1983) [15]. Sharing the collective resources would make it possible to support users' demands among libraries. However, Cummings et al. (1993) [16] mentioned that decreasing budgets may result in university library collections becoming more alike because libraries would purchase the same essential titles. Consequently, there would be the decline in the richness of collections overall. If the decline in the acquisition of volumes continues, Perrault (1994) [17] pointed out that the combined resources of research libraries may be inadequate to supplement an individual library's collection.

Wilen and Ahtola (2006) [18] stated that unique titles should be considered important when building national collection. And in order to have more resources to share, unnecessary duplication of material should be avoided (Hewitt, 1986) [19]. Several collection analysis studies were employed to investigate the strength and weakness of library collections. Usually, the number of overlaps and unique titles were calculated in these studies. Cooper et al. (1975) [20] reported a study on the overlap ofthe monograph holdings of the UC library system. Samples were drawn from card catalogs and searches were conducted in individual library catalogs to investigate the overlap between large- and small-sized libraries. In a study by Perrault (1999) [6] , the OCLC/AMIGO Collection Analysis CD-ROM database was utilized to analyze the nonserial imprints acquired by ARL libraries. Results indicated declines in the number of monographs purchased and the number of unique titles. The author further explained that the numbers of core titles were increasing, which resulted in less diversity in title and subject coverage among libraries. The same tool was employed by Holleman (1997) [21] to investigate the collection trends of American academic libraries.

Evaluating the effectiveness of resource sharing activities is extremely important. Lancaster (1993) [22] indicated that an effective coordinated collection development program would satisfy more demands from member libraries' resources. Document delivery tests are often used to measure a library's capability to fill users' needs. Hall (1985) [23] suggested that samples from standard bibliographies or in-print bibliographies could be employed to check against library holdings. This kind of test could also be used to compare the capabilities of different libraries. Orr et al. (1968) [24] indicated that a sample of 300 items is large enough to measure a library's document delivery capability.

\section{FEASIBILITY OF ASEAN LIBRARY DIGITAL RESOURCES DEVELOPMENT AND SHARING IMPLEMENTATION}

The implementation of development and sharing ASEAN literature digital resources has been a consensus among ASEAN libraries. The ways, time and cost needed to obtain literature information resources are more important than the location they get the resources, from global users' points of views. As to libraries, the implementation of ASEAN libraries's digital resources document development and sharing is the fundamental guarantee to meet the psychological needs of the users.

All the libraries have accumulated some experience. With the development of automation and network, in late last century, national libraries were active in development and sharing literature information in different industries. These not only realized the regional, national, regional trans-system development and sharing but also successfully lead to the international and intercontinental library cooperation.

The National Library of Singapore promotes learning and research with the nation's heritage collection and supports the creation of original content. The followmg initiatives, namely NewspaperSG, BookSG and PictureSG highlight some of the National Library of Singapore's efforts in sharing its heritage resources.

NewspaperSG (http://newspapers.nl.sg) is an popular online resource of current and historic Singapore and Malaya newspaper. General users and researchers can search digital archive of newspaper published between 1831 and 2009. NewspaperSG archived a yearly average of 6.5 million page view and digital visitorship of 1.2 million.

BookSG (http://sgebooks.nl.sg) is an online set of books and other printed material digitised from the collections of the National Library of Singapore and selected works digitised from the British Library's Oriental \& India Office Collection. At present, there are more than 15,000 titles available via the microsite. These comprise rare and historical materials related to Singapore and Southeast Asia, including old hikayats and syairs published in Singapore such as Ilikayat Abdullah. BookSG also provides access in "limited preview" formats to works published in Singapore between 1950s and 2005 which are held in the Depository Collection of the National Library of Singapore.

PictureSG (http://pictures.nl.sg) is a collection of pictures that provide information about the socio cultural and historical development of Singapore. This website, officially launched on 28 November 2011, is a showcase of yet another of the National Library of Singapore continued efforts in preserving the nation's heritage and ensuring the accessibility of its vast and rich resources to the masses. The portal has an estimated 20,000 images in this initial phase (Chou Wun Han, 2012) [25].

In Brunei, digital libraries, digitalization and digital collection, metadata, e-resources and electronic journals etc. has become a reality with the many initiatives of the Brunei Government. We have e-library@ubd: VILIS Brunei (Virtual Library and Information Systems), e-RIS of ITB' e-library of KUPU SB. The e-library@ubd vision is a dedicated Online Catalogue to search the UBD library catalogue information including books which is/are on orders and can undertake searches on the specific field or a combination of field of the items looking for. The system also allows to check the 
account information as Lending, Fines, and Reservation. It also provides a comprehensive and dynamic digital library for supporting academic research and nation's knowledge agenda.

Dewan Bahasa dan Pustaka Library popularly known as the public and national library of Brunei Darussalam provides direct interaction and communication to users with various library services such as loan, references, counseling, and information counter. Under the 9th Negara Brunei Darussalam National Development plan, Dewan Bahasa dan Pustaka Library has been allocated with 10 million Brunei Dollars for the implementation of E-Library Project for the governmental department libraries throughout the country. The Dewan Bahasa dan Pustaka Library is the leading agency for this project for the governmental department libraries and at the same time act as the centre of national digital collection of local publication in Brunei Darussalam (BRUNEIANA) (Haji sahari bin haji nassar, 2012) [26].

The National library of the Philippines through its Bibliographic Services Division - Information and Technology Center staff in cooperation with the Filipiniana Staff, started scanning some of its photo collection In 1997. In its cultural resources preservation program, the National library of the Philippine has proposed in the 1999 Budget for the digitization project of some selected rare books and manuscripts collections, which is projected for implementation in 2000 and operational by the year 2001 2002.

The initiative to develop digital library services in the National library of the Philippine is a product of the institutions active participation in the organization and management of Philippine e-lib. Philippine e-lib was organized and formally launched in 2005, funded through the e-Government Fund of the Philippine Government, hopes to provide for the information needs of all sectors of society in a convenient, affordable, and efficient way of delivery. It consists of the five (5) different agencies, National Library of the Philippines (NLP), University 6 Philippines (UP), Department of Science and Technology (DOST), Department of Agriculture (DA), and the Commission on Higher Education (CHED). It opened the opportunity to NLP to adequately digitized Filipiniana materials (Antonio $\mathrm{M}$. Santos, 2012) [27].

Digitization programme of National Library of Malaysia's collection and in house publications started in 1998. Among the objectives of digitization initiatives in Malaysia are to promote Malaysiana digital resources globally and to preserve the intellectual heritage; to increase access to Malays.ana resources; and to develop and maintain a national collection and to make these materials accessible to all Malaysians anytime and anywhere. National Library of Malaysia provide public domain as well as subscribed and purchased e-resources to the users by widening its access to its electronic resources to all Malaysians through National Library of Malaysia's Elcctromc Resources Portal (http://pnmdigital.com) or digital Resources@NLM effective 1 March 2012. This is a single sign on portal to all the electronic resources in the library and can be access anytime, anywhere and by anyone through personal computer, tablet computer laptop smart phone and other electronic gadgets. This service is provided free to all Malaysians and is a "touch point" for the government to develop a knowledge socety towards realizing Vision 2020 where Malaysia hope to achieve the status of a developed nation. Every Malaysian can access this electronic resources portal by $\mathrm{reg}^{\wedge}$ stenng as an onlme member through http://pnmd.gital.com or the National Library of Malaysia Official Portal http://www.pnm.gov/my. As-at May 2012, 2000 people has registered as an online member and 29,914 people have visited the portal. The content of electronic resources that can be access through this portal include e-book, e-joumal, e-magazine, e-newspaper, e-catalogues, audio books and online databases (Dato' Raslin Abu Bakar, Chin Loy Jyoon and Nor Obaidah Abidin, 2012) [28].

The National Library of Myanmar Website (http://www.nlm.gov.mm) has been developed in 2007. The information about the National Library of Myanmar and data of library collections can be accessed by the website. In 2011, National Library of Myanmar has been implemented the special project for e-library services with the cooperate of Cultura library. This project will play better and more effective sharingresources. Over 12128 e-book will be available at The National Library of Myanmar. All of the e-resources are searched by author, title, subject or keyword through e-library management software. The online catalogue and a list of e-resources by category. Such as: Books on Myanmar collection comprises publiccations on Myanmar. It is important collection of Myanmar. This collection has been digitized for e-books resources. People can get information on Myanmar by using machine-readable form; Race book collection includes printed books publicshed before and in 1900 including the earliest publication; Alphabetum Burmanum public in 1776. In seria, published before 1948. The rare books collection includes various subject. Digitization of those has been initiated using in-house system (Kay Thi Aye, 2012) [29].

The Digital Library of Lao Manuscripts web application was officially launched in Vientiane in January 2010, and can be viewed at http://www.laomanuscripts.net. It provides free online access to digital images of almost 12,000 palm-leaf and other traditional texts from throughout Laos. In 2007, the National Library of Laos began a three- year project to digitise over 1,000 rolls of microfilm copies of manuscripts from throughout the country and to make its national literary heritage freely available via the Internet. The Digital Library of Lao Manuscripts database contains inventory data for the collection of almost 12,000 texts, together with some 500,000 digital images of the manuscripts. Data is entered in both Lao and Romanised/English, and can be searched by title, ancillary term, language, script, category, material, location, date, and code number (Khanthamaly Yangnouvong, 2012) [30].

The National Library of Vietnam started building informtion and digital library since 1986 and strongly implementted since 2001 with nearly 480,000 bibliographic of more than 1.5 million coppies, more than 65.000 press clippings of newspaper and special journals and with more than 25,000 materials. This is the race and special of the National Library of Vietnam and the most sufficient thesis collection of Vietnamese people which is protected at home and abroad. Regarding the international cooperration and material exchange, the NLV National Library of Vietnam currently has the material exchange programs with 70 libraries and 30 countries all over the world (Nguyen Xuan 
Dung, 2012) [31].

All ASEAN library's database sharing has developed a lot. These experiences have laid the foundation for further development of international resource sharing activities.

\section{THE Possible IMPEDIMENT IN THE ProJECT OF ASEAN Digital RESOURCES SHARING AND CONSTRUCTION}

The differences on language \& culture, management system, laws, and economy development bring some obstacles in digital resources construction and sharing project. We recognized the obstacles as follow:

First, language barrier is the biggest one in the project. Some digital resources from one country could not be used by another people because they have never learnt the language. They could solve the problem by translation; however, it becomes a huge task in that there are many languages in ASEAN countries. Different coding Computer brings difficulties to the cross cultural communication which needs solving in a special way.

The second is the investment barriers. Effective food is the premise condition of Co-construction and sharing of digital resources. Since ASEAN countries are all developing countries, economic level has to be further improved. The economic development level of all countries is not balanced, so the library construction investment appears generally insufficient and unbalanced, which can not adapt to the need of the co-construction and sharing of digital resources, therefore, it needs to establish the effective fund guarantee system.

The third is organization barriers. Because of it's multitask, digital resource Co-construction is the most important to establish an effective and unified structure, which needs considering because of the obstacles that differences on languages, cultures and systems brings.

The forth is intellectual copyright barrier. Intellectual Copyright is the key to digital resource construction project to which should be attached importance. Now it has some law and copyright differences between ASEAN countries, so the problem of intellectual copyright has been complicated more and more. Only would they get over the barrier, Co-construction project could be legitimate in the future.

The fifth is no common criterion for human resources and technology. No common regulation and different technological standard affects the Co-construction project. So we need to employ more staffs who are adept to computer science, library science and second language. Only will we cultivate more employees of ability, this task of digital resources co-construction could be developed well.

\section{THE ASEAN Library Digital ResourCes Sharing SOME SUGGESTIONS}

\section{A. Working Together for Overcoming Language Difficulty}

Language problems must take precedence of other questions for Digital Resources Construction and Sharing in Libraries of ASEAN. It is important to choose one official languages for the cooperation. Moreover, establishing a base for the official languages is also necessary, which cloud handled the jobs concerned of language translations and the format transformations.

\section{B. Establishing and Ensuring the Fund}

Considering the spending of libraries in ASEAN countries, there's need to establish and ensure the fund for Digital Resources Construction and Sharing in Libraries of ASEAN. Methods of utilizing the fund would be diversified. ASEAN government investment, the enterprise supporting and individual donations, are technically feasible.

\section{Organizing the Administrations}

Referring to organization and management of international organizations, the headquarters of Digital Resources Construction and Sharing in Libraries of ASEAN, should be built. In the future the administrative branches should be set step by step. Besides, it need hire expert advices from librarianship consultants and bureau. Finally, a good organization not only depends on efficiency, and the evaluating and assessment as well. So the evaluating job is important part of complete working organs and mechanisms (Zhou Qingsong, 2012) [32].

\section{Building Digitalized Sharing Platform}

The prerequisite of information resources sharing is common knowledge, of which the most effective insurance is coherent standards and regulation. Therefore, data collection, indexing, processing, input must be strictly carried out in accordance with international standards, and standards and specifications of the database construction must be improved when online cataloging international books and documents. Standard specifications are the basis of digital library construction, and also fundamental insurance of digital resources development and sharing. To achieve the interoperability of digital library systems in ASEAN, they must combine the actual needs of the national digital library construction and service, set up operation regulations around the core business, give priority to well-established international standards on the principle of "joint, open and share".

\section{E. Digital Document Copyright Lack of Legal Protection}

The legal platform of library information resources sharing refers to laws and regulations related to various information resources development and sharing. The document data development and sharing is for the library to meet the demand international standards. There will be some new issues such as copyright, network security, information controlling and so on. The legislation on digital works copyright is not clear. Rapid developments of computer technology, automation technology and network technology make transforming document resources format convertion, duplicating, downloading digitalized works and piracy easier. Intellectual property protection of digital works is more complex and prominent than the traditional paper document. According to Copyright Law, obtaining the owner's consent must goes before using his works. The digital resources are so big that it is rather difficult to get the owner's authorization of every work in reality. The laws which are inconsistent with self-construction and development characteristics cannot be applied in the digital library of relevant legislation.

\section{F. Pay Attention to Improve the Librarians' Abilities}

Library resources development and sharing in the network environment are very complicated. New digitalization technology, network technology and automation technology 
have brought great changes to library service model, and it puts forward higher requirements for the quality and ability of the librarians. In addition to good political thought, professional ethics, professional knowledge, librarians should keep pace with the time and master the network technology, digital communication skills and foreign language. Only in this way, librarians can be competent to the work in the network environment and provide readers full, accurate and efficient service.

\section{CONCLUSION}

Sharing of information resources is the library an important indicator of the level of development. The construction of information resource sharing strategy has become an important issue facing libraries. It is important that libranes to establish a correct concept of literature resource sharing, the establisment of information resource sharing of the management, strengthens the construction characteristics of networks information resources, so that library construction and sharing of information resources in order to further improve the collection of resources to sustainable development. Librarians in ASEAN countries should seize the opportunities to learn the significance of Co-construction project, solve the problems and make the resource snaring project to be beneficial to economy and all people in ASEAN countries.

\section{REFERENCES}

[1] A. Kent, "Resource sharing," in Encyclopedia of Library and Information Science, A. Kent and H. L. Lancour, Eds. New York: Dekker, 1978, vol. 25, pp. 41-45.

[2] T. A. Chrzastowski and M. A. Anthes, "Seeking the $99 \%$ chemistry library: extending the serial collection through the use of decentralized document delivery," Library Acquisitions Practice and Theory, vol. 19 no. 2, pp. 141-152, 1995.

[3] S. H. Lee, "Management for research libraries cooperation," Journal of Library Administration, vol. 29, no. 3/4, pp. 1-4, 2000.

[4] D. Z. Jordan, "Purchasing or borrowing: making interlibrary loan decisions that enhance patron satisfaction," Journal of Interlibrary Loan, Document Delivery and Electronic Reserve, vol. 18, no. 3, pp. 387-394, 2008.

[5] P. Street, "Centre stage or just a supporting role? International interlending in the twenty-first century: a UK perspective," Interlending and Document Supply, vol. 31, no. 4, pp. 246-252, 2003.

[6] A. H. Perrault, "National collecting trends: collection analysis methods and findings," Library and Information Science Research, vol. 21, no. 1, pp. 47-67, 1999 .

[7] G. E. Evans, and M. Z. Saponaro, Developing Library And Information Center Collections, 5th ed. Westport, Conn.: Libraries Unlimited, 2005.

[8] American Library Association. (2008). Interlibrary Loan Code for the United States. [Online]. Available at:http://www.ala.org/ala/mgrps/divs/rusa/resources/guidelines/ interlibrary.cfm.

[9] N. Egan, "The Impact of electronic full-text resources on interlibrary loan: a ten-year study at John Jay College of Criminal Justice," Journal of Interlibrary Loan, Document Delivery and Electronic Reserves, vol. 15 , no. 3, pp. 23-41, 2005.

[10] L. Wiley and T. Chrzastowski, "The impact of electronic journals on interlibrary lending: a longitudinal study of statewide interlibrary loan article sharing in Illinois," Library Collections, Acquisitions, and Technical Services, vol. 29, no. 4, pp. 364-381, 2005.

[11] A. Beaubien. (June 2007). ARL white paper on interlibrary loan. [Online]. Available: http://www.arl.org/bm doc/ARL_white_paper_ILL_june07.pdf

[12] J. Walton, "The changing use of electronic document delivery in the inter-library loan service: a survey," Interlending and Document Supply, vol. 36, no. 1, pp. 43-56, 2008.
[13] M. E. Jackson, "Research collections and digital information. Will there be a role for interlibrary loan and document delivery services?' Journal of Library Administration, vol. 31, no. 2, pp.15-25, 2000.

[14] L. Porat and S. Fine, "Factors and characteristics of interlibrary loan use and non-use," Interlending and Document Supply, vol. 37, no. 1, pp. 20-27, 2009.

[15] J. Fletcher, "Collection development \& resource sharing," Library Journal, vol. 108, no. 9, pp. 881-882, 1983.

[16] A. M. Cummings et al., "A study prepared for the Andrew W," University libraries and Scholarly Communication, Mellon Foundation Washington, D.C.: Association of Research Libraries, 1993.

[17] A. H. Perrault, "The shrinking national collection: a study of the effects of the diversion of funds from monographs to serials on the monograph collections of research libraries," Library Acquisitions: Practices and Theory, vol. 18, no. 1, pp. 3-22, 1994.

[18] R. Wilen and A. Ahtola. (2006). Collection evaluation: micro and macro levels - guidelines and the results of a pilot study of two Finnish University libraries. [Online]. Available: http://www.pro.tsv.fi/STKS/signum/200603/7.pdf

[19] J. A. Hewitt, "Cooperative collection development programs of the triangle research libraries network," Resource Sharing and Information Network, vol. 2, no. 3/4, pp. 139-150, 1986.

[20] W. S. Cooper, D. D. Thompson, and K. R. Weeks, "The duplication of monograph holdings in the University of California Library System," Library Quarterly, vol. 45, no. 3, pp. 253-274, 1975.

[21] C. Holleman, "The study of subject strengths, overlap, and national collecting patterns: the use of the OCLC/AMIGOS Collection analysis $\mathrm{CD}$ and alternatives to it," Collection Management, vol. 22, no. 1/2, pp. $57-69,1997$

[22] F. W. Lancaster, If You Want to Evaluate Your Library, 2nd ed. London: Library Association Publishing, 1993.

[23] B. H. Hall, "Writing the collection assessment manual," Collection Management, vol. 6, no. 3/4, pp. 49-61. 1985.

[24] R. H. Orr et al., "Development of methodological tools for planning and managing library services: II. Measuring a library's capability for providing documents," Bulletin of the Medical Library Association, vol. 56, no. 3, pp. 242-267, 1968.

[25] W. H. Chou, "Bringing our heritage resources to your door step: the national library of singpore's experrience," Asian Libraries: Resource Sharing, Copperation and Development, 2012 China-ASEAN Cultural Forum, pp. 1-8, 2012.

[26] H. S. B. H. Nassar, "Digitalisation in negara brunei darussalam," Asian Libraries: Resource Sharing, Copperation and Development, 2012 China- ASEAN Cultural Forum, pp 16-19, 2012.

[27] A. M. Santos, "Digital library services division in the national library of the philippines: towards resource sharing in the asean," Asian Libraries: Resource Sharing, Copperation and Development, 2012 China- ASEAN Cultural Forum, pp. 25-32.

[28] D. R. A. Bakar et al., "Document resources co-construction and sharing national library of Malaysia," Asian Libraries: Resource Sharing, Copperation and Development, 2012 China- ASEAN Cultural Forum, pp. 33-44.

[29] K. T. Aye, "Document resources co-construction and sharing of national library of myanmar," Asian Libraries: Resource Sharing, Copperation and Development, 2012 China- ASEAN Cultural Forum, pp. $45-54$

[30] K. Yangnouvong, "The digital library of lao manuscripts," Asian Libraries: Resource Sharing, Copperation and Development, 2012 China- ASEAN Cultural Forum, pp. 75-83.

[31] N. X. Dung, "The national library of vietnam in the international integration process," Asian Libraries: Resource Sharing, Copperation and Development, 2012 China- ASEAN Cultural Forum, pp. 84-87.

[32] Q. S. Zhou, "Construction and sharing of library digital resources in china and southeast asia," Asian Libraries: Resource Sharing, Copperation and Development, 2012 China, ASEAN Cultural Forum, pp. 154-164.

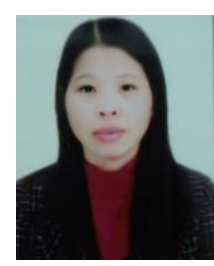

Do Thi Thanh Thuy was born in 1978 in Vietnam. She received her master's degree in library and information science from Hanoi Culture University, Vietnam. Since 2011, she is doing her doctor's degree student study library science in Wuhan University. She has been working as a librarian in Library of Bacgiang Province. Her research areas are digital library and resource sharing. 